\title{
A SEGUNDA ALMA DO PARTIDO DOS TRABALHADORES
}

\author{
ANDRÉ SINGER
}

\section{RESUMO}

Os dois mandatos de Lula formaram a síntese contraditória das "duas almas" que hoje habitam o PT. Foi o fato de ter implementado, simultaneamente, políticas que beneficiam o capital e promovem a inclusão dos mais pobres, com uma melhora relativa na situação dos trabalhadores, que permitiu a convivência dos princípios estabelecidos em sua fundação, no colégio Sion em 1980, e as diretrizes do programa de governo apresentadas em 2002 na convenção do Anhembi, em São Paulo.

PALAVRAS-CHAVE: Partido dos Trabalhadores; governo Lula; fundação do PT; Carta ao Povo Brasileiro.

\section{ABSTRACT}

Lula's presidency seem to have blended PT's two apparently contradictory "souls". By implementing policies that favor capital while at the same time foster the social inclusion of the poor, and that have also improved working class citizens' life standards, Lula has been able, as a president, to preserve the ideals that animated the party's foundation and the more pragmatic programme for government set out in 2002 . KEYWORDS: Worker's Party (PT); Lula's presidency; foundation of the Worker's Party (PT); Letter to the Brazilian People.

[1] Citado em Schorske, Carl. German Social Democracy (1905-1917): the development of the great schism. Cambridge (Mass.), Harvard University Press, 1983, p. 290 (trad. livre).
Oconflito de duas almas em um mesmo peito provavelmente não era fácil para nenhum de nós. Konrad Haenisch, sobre o Partido Social-Democrata da Alemanha ao votar os créditos de guerra, em agosto de $1914^{1}$.

A transformação do Partido dos Trabalhadores (PT) salta à vista de quem, por diferentes motivos, acompanha o percurso da agremiação fundada em fevereiro de 1980 no Colégio Sion, em São Paulo. Militantes percebem, dia a dia, que antigas práticas já não vigoram, cedendo lugar a condutas inusitadas pelos critérios de antes. Jornalistas acostumados aos vaivéns da política brasileira, com frequência, assinalam o contraste entre o passado e o presente do partido. A literatura acadêmica se esforça para dar conta do sentido das mudanças pelas quais passa o PT. Entender os rumos do partido tornou-se um dos assuntos prediletos do debate informado no Brasil. 
A dificuldade está em, como escreveu sobre outro tema Gildo Brandão, tratar-se de matéria rebelde ${ }^{2}$. Quando parece fixar-se uma forma por exemplo, a de grupo pragmático - eis que surge a sombra da velha ideologia na diretriz para o programa presidencial. Quando se pensa divisar a passagem para o lado da ordem, um congresso partidário reafirma, por unanimidade, a convicção socialista. Afinal, aonde vai o PT? Na bibliografia especializada, pode-se distinguir quatro macro-orientações (sem atentar aos diversos aspectos que singularizam cada contribuição). A primeira detém na crescente moderação do discurso. Com tonalidades distintas, a depender da inclinação do autor, um conjunto de trabalhos nota queo PT não pretende mais revolucionar a sociedade 3 . Uma segunda vertente concentra-se na passagem de um partido acentuadamente ideológico, com inserção eleitoral distinguida por tal traço, para uma legenda com acento maximizador, isto é, disposta a qualquer ação para conseguir votos ${ }^{4}$. Em terceiro, estão os que apontam para o enfraquecimento do vínculo com os movimentos sociais e uma paralela inserção privilegiada no Estado. Ainda na linha de fechamento dos canais de participação, e olhando para as formas de organização interna, indicam a transição de uma estrutura na qual as bases tinham peso - com a existência de núcleos militantes e contribuição financeira dos membros - para uma em que a cúpula profissionalizada tende a dar as cartas e o financiamento é externo5. Por fim, estão os textos que salientam o câmbio na origem social dos simpatizantes, com uma intensa popularização das fontes de apoio ${ }^{6}$.

Apesar de o interesse da ciência política no caso do PT ter propiciado um painel rico e nuançado dos diversos aspectos que compõem a saga petista, o qual se completa por meio de uma produção que busca relacioná-la a elementos de natureza estrutural na sociedade brasileira7, restam perguntas no ar, como a que ressoa em um dos títulos acima mencionados: "O Partido dos Trabalhadores:ainda um partido de esquerda?". O presente artigo procura responder às questões abertas, consciente de operar em terreno escorregadio. Parte-se de uma dupla hipótese: a de que o realinhamento eleitoral ocorrido entre 2002 e 2006 , de um lado, fez surgirum novo "partido dos pobres", conforme antecipou Fábio Wanderley Reis em entrevista publicada em outubro de 2004, com características que lembram as do PTB anterior a $1964^{8}$. De outro, que a história do PT, vincada por uma rara conexão entre classe e ideologia radical, constituiu uma alma que ainda o influencia. O PT, em consequência, não poderia ser entendido fora da síntese contraditória que as duas facetas compõem.

\section{O REALINHAMENTO dE 2002 A 2006 E SUAS CONSEQUÊNCIAS}

Se dermos um passo atrás, verificaremos que em outubro de 2002 , no auge da campanha que levaria Lula à presidência da República, o PT atingia a condição de líder isolado na preferência dos eleitores.
[2] Para os que acompanharam a trajetória de Gildo Marçal Brandão, saudoso colega do Departamento de Ciência Política da Universidade de São Paulo, não escapará que o título deste artigo alude também ao seu livro $A$ esquerda positiva, as duas almas do Partido Comunista, 1920/1964. São Paulo, Hucitec, 1997.

[3] Ver Amaral. Oswaldo E. do. $A$ estrela não é mais vermelha. São Paulo, Garçoni, 2003; Samuels, David. "From socialism to social democracy". Comparative Political Studies, vol. 37, nº 9, 2004, pp. 999-1024; Silva, Antonio Ozaí da. "Nem reforma nem revolução: a estrela é branca”. In: Angelo, V. A. de e Villa, M. A. (orgs.). O Partido dos Trabalhadores e a política brasileira (1980-2006). São Carlos, EdUFSCar, 2009.

[4] Ver Hunter, Wendy. "The normalization of an anomaly, the worker's party in Brazil". World Politics, vol. 59, abr. 2007,440-75; Ibidem. "The Partido dos Trabalhadores: still a party of the left?". In: Kingstone, P. R. e Power, T. J. (orgs.). Democratic Brazil revisited. Pittsburgh, University of Pittsburgh Press, 2008.

[5] Ver Ribeiro, Pedro Floriano. "O PT, o Estado e a sociedade". In: Angelo e Villa, op. cit.; Samuels. "A democracia brasileira sob o governo de Lula e do PT". In: Ibidem.

[6] Ver Veiga, Luciana Fernandes. "Os partidos brasileiros na perspectiva dos eleitores: mudanças e continuidades na identificação partidária e na avaliação das principais legenda após 2002". Opinião Pública, vol. 13, $\mathrm{n}^{\circ}$ 2, 2007, 340-65; Venturi, Gustavo. "PT 30 anos: crescimento e mudanças na preferência partidária, impacto nas eleições de 2010". Perseu, n $^{\circ}$, 2010,197-214.

[7] Ver Oliveira, Francisco de. "Política numa era de indeterminação: opacidade e reencantamento" e "O momento Lênin". In: Oliveira e Rizek, C. S. (orgs.). A era da indeterminação. São Paulo, Boitempo, 2007; Guimarães, Juarez. A esperança crítica. Belo Horizonte, Scriptum, 2007; Árabe, Carlos Henrique Goulart. Desenvolvimento nacional e poder politico, o projeto do Partido dos Trabalhadores em um período de crise. Campinas: dissertação de mestrado, Unicamp, 1998. 
[8] Cariello, Rafael. "PT e PSDB fazem polarização de pobres e ricos, diz analista". Folha de S. Paulo, $8 / 10 / 2004$.

[9] Agradeço ao Centro de Estudos de Opinião Pública (Cesop) da Unicamp a cessão de dados do Instituto Datafolha, e a Silvia Elena Alegre, pela imprescindível ajuda no tratamento do material.
[10] Veiga, op. cit., p.362.
À medida que a candidatura petista se fazia majoritária, o partido distanciava-se do PMDB, do PSDB e do ex-PFL (hoje Democratas), seus competidores diretos. Às vésperas da alternância no poder, $21 \%$ dos consultados em survey nacional afirmavam ter simpatia pelo PT, enquanto o PMDB era indicado por $8 \%$, e o PSDB, por apenas $4 \%$. Quase oito anos depois, os números encontrados diferem pouco: o PT tinha $24 \%$ das menções, enquanto o PMDB se encontrava com $6 \%$ e o PSDB, com outros 6\% (Tabela 1). Mas, assim como aconteceu com o fenômeno do lulismo, sob superfície semelhante esconde-se uma troca nos estratos sociais do petismo?.

TABELA 1

Preferência partidária (resposta espontânea e única), 1989-2010

\begin{tabular}{|c|c|c|c|c|c|c|c|c|c|}
\hline \multirow{2}{*}{$\begin{array}{l}\text { Partidos } \\
\text { Políticos }\end{array}$} & \multicolumn{9}{|c|}{ Ano } \\
\hline & 1989 & 1994 & 1996 & 1998 & 2002 & 2005 & 2006 & 2007 & 2010 \\
\hline PT & $12 \%$ & $13 \%$ & $13 \%$ & $12 \%$ & $21 \%$ & $16 \%$ & $19 \%$ & $21 \%$ & $24 \%$ \\
\hline PMDB & $19 \%$ & $18 \%$ & $13 \%$ & $12 \%$ & $8 \%$ & $5 \%$ & $7 \%$ & $10 \%$ & $6 \%$ \\
\hline PSDB & $1 \%$ & $3 \%$ & $4 \%$ & $4 \%$ & $4 \%$ & $8 \%$ & $5 \%$ & $5 \%$ & $6 \%$ \\
\hline PFL/DEM & $6 \%$ & $4 \%$ & $4 \%$ & $5 \%$ & $4 \%$ & $4 \%$ & $3 \%$ & $2 \%$ & $1 \%$ \\
\hline
\end{tabular}

Fontes: Datafolha. Abril de 1989, fevereiro de 1994, junho de 1996, setembro de 1998 e outubro de 2002, via Y.S. Carreirão e M. D. Kinzo, op. cit. pp. 144-5; dezembro de 2005, via G. Venturi, "PT 30 anos: crescimento e mudanças na preferência partidária, impacto nas eleições de 2010 ", Perseu, n 5 , junho de 2010 ; janeiro de 2006 , março de 2007, via Cesop (Unicamp); março de 2010, via 〈www.datafolha.com. br〉, acesso em 29/6/2010.

Luciana Fernandes Veiga, ao comparar os dois Estudos Eleitorais Brasileiros (Eseb) realizados logo após os pleitos de 2002 e 2006 , percebeu a alteração. A renda familiar média do simpatizante do PT havia caído de $\mathrm{R} \$ 1.349$ para $\mathrm{R} \$ 985$; houve uma redução de $17 \%$ para $6 \%$ na proporção dos que tinham acesso à universidade entre os que simpatizavam com o PT, e a participação do Sudeste entre os identificados com o partido caiu de $58 \%$ para $42 \%$. Sugere a autora:

Essa transformação no perfil do eleitor que se identifica com o PT pode estar relacionada com a perda de parte do segmento mais ideológico e mais intelectualizado entre os simpatizantes, pois muitos seguiram os seus líderes e se transferiram também para o PSOL, e a adesão de um segmento novo do eleitorado, beneficiário dos programas sociais e dos programas de inclusã $0^{10}$.

No entanto, outras análises, empiricamente fundamentadas, deixaram por algum tempo em suspenso o alcance da descoberta deVeiga. David Samuels, utilizando uma segunda fonte de dados, embora con- 
firmasse a menor escolarização e diminuição da influência do Sudeste entre os apoiadores do PT, sugeriu que as diferenças tinham sido de "baixo grau". Em particular, considerou pouco provável que os programas do governo federal, em particular a Bolsa Família (BF), houvessem atraído para o partido os eleitores de baixíssima renda. Em consequência, o petismo teria permanecido "não associado à pobreza" .

Em direção semelhante, ao estabelecer distinções entre o desempenho do lulismo e do PT na eleição de 2006 , Wendy Huntere Thimoty Power haviam afirmado, a partir da análise dos resultados por região geográfica do país, divididos em função do IDH, que "enquanto Lula obteve seu desempenho mais notável nas regiões menos desenvolvidas (os chamados "grotões", calcanhar de Aquiles histórico do PT), o baluarte do partido continuou sendo as zonas mais urbanizadas e industriais do Brasil"12. Os autores mostraram que o montante de votos em Lula e no PT para a Câmara dos Deputados, por Estado da federação, estava positivamente correlacionado em 1994, 1998 e 2002 , mas não em 2006. Isto é, em 2006, os lugares em que Lula foi melhor não foram os mesmos que deram a maior votação às listas de candidatos parlamentares petistas. Hunter e Power chamaram a atenção, igualmente, para o fato de que a distância entre a votação de Lula e do PT aumentava conforme caía o IDH do Estado ${ }^{13}$. Em outras palavras, nos Estados mais pobres, o expressivo contingente que votou em Lula em 2006 não repetiu o gesto em relação ao PT.

Embora parcialmente corretas e relevantes, as observações de Samuels, de um lado, e de Hunter e Power, de outro, tenderam a obscurecer a dimensão e a direção das forças que afetaram o PT. Para distingui-las, é necessário olhar da perspectiva da própria trajetória partidária, pois a comparação com a dramática virada que aconteceu com Lula em 2006 sombreia e borra o ocorrido com o partido.

Se recortarmos o período que vai de meados dos anos de 1990 até a primeira década do século XXI, veremos com nitidez algumas das mutações do PT. A primeira diz respeito à sua expansão. Se em 2001, quando se deu o primeiro Processo de Eleição Direta (PED) para escolha do presidente da sigla, o partido já reunia 500 mil filiados, em função de quase vinte anos de empenho organizativo, por ocasião do quarto PED ${ }^{14}$, oito anos depois, esse número havia mais do que duplicado, com quase 1,2 milhão de aderentes, tendo subido, entre $2002 \mathrm{e}$ 2009 , de quarto para segundo colocado entre os partidos brasileiros quanto ao número de filiados, superando tucanos e Democratas ${ }^{15}$.

Aquantidade de municípios governados pelo PT triplicou no período. Em 2000, eram 187, pulando, em 2008, para $559^{16}$. A quantidade de cidades em que há diretórios do partido saltou de 40\% em 1993 para $96 \% \mathrm{em} 2009^{17}$. A bancada petista no Senado Federal aumentou de três membros em 1998 para dez em 2006. O partido elegeu três
[11] Samuels. "A evolução do petismo". Opinião Pública, vol. 14, $\mathrm{n}^{\circ} 2$, 2008, pp.302-18, p.315.

[12] Hunter, Wendy e Power, Thimoty. "Recompensando Lula: poder Executivo, política social e as eleições brasileiras em 2006". In: Melo, C. R. e Sáez, M. A. (orgs.).A democracia brasileira: balanço e perspectivas para o século 21. Belo Horizonte, Editora UFMG, 2007, p. 338.

[13] Ibidem, pp. 338-9.

[14] Para o dado de 2001, ver Singer, André. O PT. São Paulo: Publifolha, 2001, p. 87. Agradeço a Roseli Coelho ter-me chamado a atenção para o fato de haver crescido de maneira expressiva a filiação ao PT depois do início do governo Lula.

[15] Os petistas ainda perdem nesse quesito para os peemedebistas, os quais somavam 1,9 milhão de inscritos, quantidade, porém, que vêm caindo com o passar do tempo, ao contrário do que acontece com o PT. Ver $\langle$ http//g1.globo.com〉, acessado em 18/5/2010.

[16] Grupo de Trabalho Eleitoral (GTE) do PT, 2008.

[17] Machado, Uirá e Puls, Mauricio. "Aprovação mais alta do PT projeta bancada recorde". Folha de S. Paulo, 2/8/2010, p.A12. 
[18] Ibidem. Utilizamos tais projeções, pois o presente artigo foi concluído em setembro de 2010, antes, portanto, do pleito previsto para $3 \mathrm{de}$ outubro de 2010.

[19] Meneguello, Rachel.PT, a formação de um partido. Rio de Janeiro: Paz e Terra, 1989, p. 173.

[20] Keck, Margareth. PT, a lógica da diferença. São Paulo:Ática,1991, p. 275.

[21] Mainwaring, Scott, Meneguello, Rachel e Power, Timothy. Partidos, conservadores no Brasil contemporâneo. Rio de Janeiro: Paz e Terra, 200o, p. 66.

[22] Samuels, "A Evolução do petismo, op. cit., p. 313 .

[23] Carreirão, Yan de Souza e Kinzo, Maria D'Alva. "Partidos políticos, preferência partidária e decisão eleitoral (1989/2002)". Dados, vol. $47, \mathrm{n}^{\circ}$ 1, 2004, pp.131-68, p. 150. governadores em 1998 e cinco em 2006. A menor taxa de incremento deu-se na Câmara dos Deputados, em parte devido ao recuo ocorrido em 2006, mas a comparação com a legislatura 1998-2002 mostra um progresso de quase $50 \%$ (de 59 para 83 cadeiras), devendo este indicador aumentar em $2010^{18}$.

Não obstante o recuo de 2006, o PT passou do quinto para o segundo lugar na proporção de assentos na Câmara dos Deputados entre 1998 e 2006, ficando atrás apenas do PMDB. No Senado Federal, embora tenha permanecido em quarto lugar, a distância do PT em relação ao primeiro colocado (novamente o PMDB, mas desta feita empatado com o DEM) caiu de $27 \%$ para $10 \%$, entre 1998 e 2006 , na proporção de cadeiras ocupadas naquela Casa.

Com isso, o PT ingressou no bloco dos grandes partidos, onde divide, com PSDB, PMDB e DEM, a condição de ser uma das principais agremiações políticas brasileiras, estando, em alguns quesitos, até mesmo acima das demais, e constituindo-se, sob certos critérios, no principal partido do país. Se continua atrás do PMDB no número de filiados, governadores, senadores e deputados federais, o PT ultrapassou a antiga legenda oposicionista no que diz respeito à identificação partidária, com uma larga dianteira (cf. Tabela 1).

O que nos interessa, em particular, é assinalar que o partido adquiriu, a partir de 2002 , uma ressonância popular inédita. Os estudos sobre o PT haviam até então sublinhado reiteradamente que a simpatia por ele diminuía entre os segmentos de baixa renda e escolaridade. Tal marca constava dos surveys de 1982, ocasião das eleições inaugurais para o partido. A partir dos levantamentos feitos à época, Rachel Meneguello escrevia que a proposta do PT havia atingido "um público sócio-economicamente diferenciado, pertencente a estratos mais favorecidos da população"19 (com exceção da capital paulista). Ao cabo dos anos de 1980, Margareth Keck reiterava que "embora o partido tenha ampliado a concepção inicial da sua base na classe trabalhadora", ele continua a "sensibilizar um segmento ativo e organizado da sociedade civil brasileira" 20 . Ao analisar dados de 1996, junto com Scott Mainwaringe Timothy Power, Meneguellovoltava a apontarque o PT se destacava entre os "eleitores com maior escolaridade" ${ }^{21}$. Em 2002, "os petistas eram mais educados do que os demais brasileiros", conforme percepção de David Samuels ao escrutinar o Eseb ${ }^{22}$. Yan Carreirão e Maria D’Alva Kinzo, ao estudar de maneira longitudinal a série de 1989 a 2000 , resumem:

Há um padrão constante em todos os registros realizados:os percentuais de preferência pelo $P M D B$ crescem inversamente ao nível de escolaridade, enquanto ocorre o contrário no caso do PT, ou seja, seus percentuais são proporcionalmente mais altos quanto maior o nível de escolaridade ${ }^{23}$. 
Assim, até o fim do século XX, o tipo de alinhamento estabelecido na década de 1970, em que o MDB se fixou como "partido dos pobres", refletia-se no sistema partidário. Também a "formação inicial do PT como um partido consolidado em torno de interesses organizados, de intelectuais e da classe média urbana progressista", na caracterização de Hunter e Power ${ }^{24}$, permanecia como um dos traços característicos da política nacional.

Se a opção pelo PT, desde o ângulo da renda (Tabela 2), evidencia, em 2002 , um crescimento em todas as faixas, é necessário ressaltar, de uma parte, que persiste expressiva diferença na faixa superior de renda (32\%) em relação à mais baixa (15\%), mas, de outra, que o partido começa a exercer uma atração significativa entre os eleitores que tinham até 5 salários mínimos de renda familiar mensal. Se isso não modifica, de imediato, a matriz pela qual a atração cresce com o rendimento do eleitor, dá ao PT uma abrangência desconhecida. O partido começa a atrair uma porção significativa da enorme quantidade de eleitores situados nas duas camadas de renda mais baixas, as quais constituíam nada menos que $76 \%$ do eleitorado, segundo o cálculo do Datafolha usado à época. Isso significa que, em 2002, o PT adquire nova feição, como se pode ver na Tabela 3. Nela, a maioria dos simpatizantes pertence, segundo o rendimento familiar, aos escalões inferiores.

Sem que a estrutura estabelecida em 2002 chegasse a se consolidar, uma segunda inflexão ocorre em 2005, quando o partido é envolvido na crise denominada pela imprensa de "mensalão". Em dezembro daquele ano, registra-se um retrocesso na predileção pelo PT, que volta a patamares típicos da década anterior (Tabela 1). Elementos coligidos por Samuels e Gustavo Venturi dão a entender que a queda pode ter sido ainda maior do que a apontada na Tabela 1, tendo em conta a tendência de aumento da preferência pelo PT ter prosseguido até as vésperas da eclosão do escândalo. Segundo Samuels, o Datafolha encontra $24 \%$ de identificação com o PT no final de 2004 e, de acordo com Venturi, a Criterium detecta $27 \%$ em abril de 2005 , pouco antes de o noticiário ser invadido pelo tema do "mensalão"25. Os dados apontam, portanto, que o episódio interrompe um ciclo de 25 anos de aumento constante do apreço pelo PT, provocando uma retração de até 11 pontos percentuais na preferência pelo partido. O efeito do episódio está razoavelmente documentado na literatura, porém não foi percebido, a não ser bem mais tarde, que ele não atingiu por igual as diferentes camadas sociais.

Ao fazer um balanço dos trinta anos do PT, em 2010, Venturi acabou por confirmar o que Veiga já havia notado ao comparar a clivagem dos eleitores que diziam preferir o PT em 2002 e 2006: houve, de fato, uma intensa popularização no período ${ }^{26}$. Todavia, restava esclarecer um paradoxo. Se Samuels, Hunter e Power estavam certos ao
[24] Hunter e Power, op. cit., p.334.

[25] Samuels. "Sources of mass partisanship in Brazil". Latin American Politics and Society, vol. $48, \mathrm{n}^{\circ} 2,2006, \mathrm{pp}$. 1-27,p.5; Venturi. "PT30 anos:mudanças na distribuição regional”. Teoria $e$ Debate, $\mathrm{n}^{\circ} 87,2010$, pp.1-27, p.15.

[26] Venturi. "PT 30 anos: mudanças na base social". Teoria e Debate, $\mathrm{n}^{\circ} 88$, 2010, p. 9. 
TABELA 2

Preferência pelo PT por renda familiar mensal, 1996-2010

\begin{tabular}{|c|c|c|c|c|c|c|}
\hline \multirow{2}{*}{$\begin{array}{l}\text { Renda } \\
\text { Familiar }\end{array}$} & \multicolumn{6}{|c|}{ Ano } \\
\hline & 1996 & 1998 & 2002 & 2006 & 2007 & 2010 \\
\hline Até 2 SM & $8 \%$ & $8 \%$ & $15 \%$ & $17 \%$ & $21 \%$ & $22 \%$ \\
\hline+ de 2 a 5 SM & $11 \%$ & $12 \%$ & $23 \%$ & $21 \%$ & $21 \%$ & $27 \%$ \\
\hline+ de 5 a 10 SM & $15 \%$ & $17 \%$ & $28 \%$ & $22 \%$ & $19 \%$ & $21 \%$ \\
\hline+ de 10 SM & $19 \%$ & $15 \%$ & $32 \%$ & $17 \%$ & $21 \%$ & $24 \%$ \\
\hline TOTAL & $13 \%$ & $12 \%$ & $22 \%$ & $19 \%$ & $21 \%$ & $24 \%$ \\
\hline
\end{tabular}

Fontes: Datafolha. Junho de 1996, via S. Mainwaring, T. Power e R. Meneguello, op. cit., p. 70; setembro de 1998 setembro de 2002, janeiro de 2006, março de 2007, via Cesop (Unicamp); 2010, via 〈www.datafolha.com.br〉, consultado em 29/6/2010.

TABELA 3

Renda familiar mensal dos que preferem o PT, 1996-2010

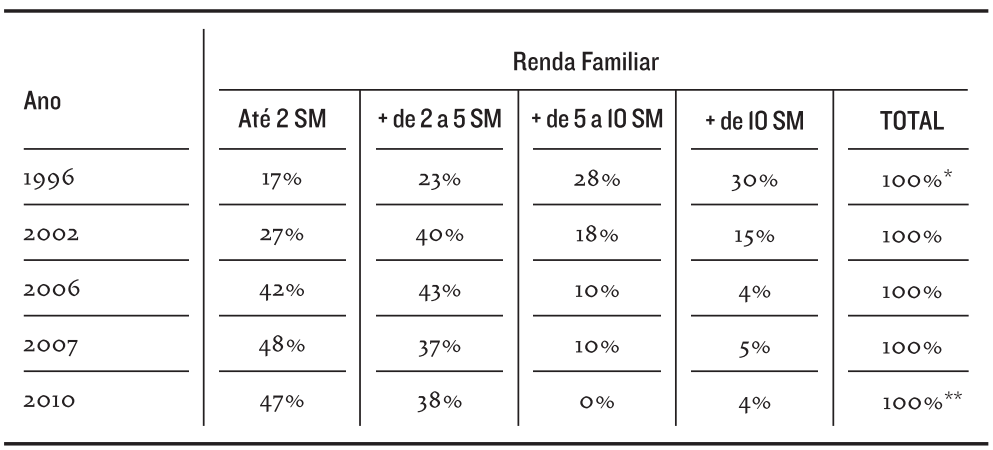

*A porcentagem não totaliza $100 \%$ porque alguns respondentes não forneceram um nível salarial.

** A porcentagem não totaliza 100\%, pois 3\% dos respondentes não forneceram um nível salarial.

Fontes: Datafolha. Junho de 1996, via S. Mainwaring, T. Power e R. Meneguello, op. cit. p. 70; setembro de 2002, janeiro de 2006, março de 2007, via Cesop (Unicamp); março de 2010, via 〈www.datafolha.com.br), consultado em 24/4/2010.

assinalar que não ocorrera uma aproximação em massa dos pobres ao PT em 2006, como acontecera com Lula, como pode ter o partido se popularizado? A resposta é dupla. De um lado, o partido já havia se popularizado ao receber um apoio inédito de eleitores de menor renda em 2002 esofreu uma nova onda de popularização, por subtração, ao perder a simpatia entre o eleitorado de classe média, retendo a sustentação popular conquistada em 2002. De fato, não aconteceu, como em relação a Lula, uma aproximação abrupta de eleitores de baixíssima renda como a que atingiu a candidatura presidencial em 2006. Porém, na comparação com o momento anterior a 2002, há uma nítida popularização do partido pelas duas razões citadas em combinação. 
Assim, a Tabela 2 mostra como em janeiro de 2006 o PT apresenta uma queda acentuada de suporte na camada de renda mais alta (acima de dez salários mínimos (SM) de renda familiar mensal (RFM)): de $32 \%$ para $17 \%$. Há também uma redução, de $28 \%$ para $22 \%$, entre os de renda familiar de cinco a dez SM. Contudo, o apoio entre os de renda mais baixa não foi afetado, com variações dentro da margem de erro, de $23 \%$ para $21 \%$ entre os que recebiam de dois a cinco SMe, há até uma elevação, de $15 \%$ para $17 \%$, entre os que recebiam até dois SM. Visto sob este prisma, pode-se dizer que o PT perdeu apelo em todas as faixas de renda menos na mais baixa, e, quanto mais al to o padrão econômico, mais forte a queda.

Segundo Venturi, depois do "mensalão", "observa-se recuperação no sentido inverso ao perfil encontrado na origem: a preferência pelo PT passa a ser decrescente quanto maior a renda $-25 \%$ entre os eleitores com RFM inferior a dois SM, contra $20 \%$ entre os eleitores com renda mensal superior a cinco SM (Criterium)" 27 . Ou seja, após o fim da crise, o PT recupera os índices de escolha (Tabela 1), porém, e esseé o elemento decisivo, de acordo com outro padrão, no qual a simpatia pelo partido tende a ser maior na metade inferior da distribuição de renda. Somados, os movimentos de afluxo popular em 2002 e afastamento da classe média em 2005 estabelecem uma imagem diferente daquela que vigorou nas primeiras duas décadas de existência do partido. A partir de 2006, a curva de sustentação do PT deixa de subir com a renda (Tabela 2). É isso que caracteriza o realinhamento, pelo qual passa a haver um absoluto predomínio dos de baixa renda entre os que se aproximam do partido, sendo que antes era o contrário (Tabela 3). Quando comparamos o ano de 1996 ao de 2010 , é fácil verificar a inversão, pela qual os petistas com renda na metade superior da distribuição caem de $58 \%$ para $12 \%$ do total, enquanto os da metade inferior sobem de $40 \%$ para $85 \%$ (Tabela3). Particularmente, os de baixíssima renda (até dois SM) passam de $17 \%$ para $47 \%{ }^{28}$.

Em consequência, a partir de 2006 modifica-se a tônica até então constante, a saber, a associação do partido com o eleitorado de maior escolaridade, coerente com a sua característica pronunciadamente ideológica. Como mostram estudos de comportamento político em diversos países, eleitores de maior escolaridade decodificam mensagens ideológicas com menor esforço. Na Tabela 4 observa-se que até 2002 prevalece a tendência de aumentar a estima pelo partido conforme crescia a escolaridade. Após 2005, o PT cai nas faixas de escolaridade mais altas, indo de $29 \%$ para $22 \%$ entre os que chegaram à universidade e de $28 \%$ para $20 \%$ entre os que tinham acesso ao ensino médio. Em compensação, fica estável a parcela dos que simpatizavam com o PT no campo dos que só tinham cursado até o ensino fundamental. Isto é, com o "mensalão", o partido perde apoio na alta escolaridade, guardando, no entanto, a preferência conquistada entre os menos escolarizados.
[27] Venturi. "PT 30 anos: crescimento e mudanças na preferência partidária".Perseu, $\mathrm{n}^{\circ} 5,2010$, p. 207. Convém notar que os dados da Criterium, utilizados na análise de Venturi, indicavam um índice de identificação com o PT de $23 \%$, em março de 2006, enquanto o Datafolha, em maio daquele ano, ainda apontava um patamar de $17 \%$. No entanto, no que se refere à mudança da distribuição da preferência pelo PT por faixa de renda, os dois institutos revelam a mesma tendência.

[28] Convém notar que os dados apurados pela Criterium para junho e outubro de 2002, assim como pela Fundação Perseu Abramo em abril de 2005, diferem dos apresentados pelo Datafolha em setembro de 2002. Embora a diferença não altere o sentido geral da interpretação aqui apresentada, ela permitiria afirmar que a mudança de fundo ocorreu em 2002, quando a proporção de eleitores de baixíssima renda, entre os que apoiam o PT, teria dobrado, indo de aproximadamente $25 \%$ para cerca de $50 \%$, não voltando aos patamares anteriores nos oito anos seguintes. Com isso, o papel da perda de apoio de eleitores de classe média, embora verificado em todos os levantamentos, seria relativamente menor. Ver Venturi, "PT 30 anos: crescimento $e$ mudanças...”, op. cit. 
TABELA 4

Preferência pelo PT por escolaridade, 1989-2010

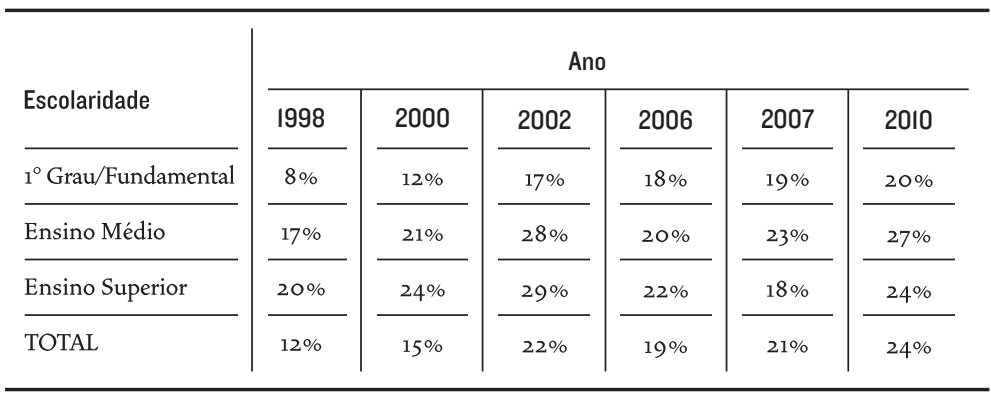

Fontes: Datafolha. Setembro de 1998, junho de 2000, via Y. S. Carreirão e M. D. Kinzo, op. cit., pp. 148-9; setembro de 2002, janeiro de 2006 e março de 2007, via Cesop (Unicamp); março de 2010, via <www.datafolha. com.br>, acessado em 24/4/2010.

Pela primeira vez, a diferença na identificação com o PT por anos de frequência à escola reduz-se à margem de erro.

A partir de março de 2007, com a perda entre os de maior escolaridade, o partido, que sempre fora mais potente entre os que tinham ensino superior, fica mais forte entre os que têm passagem pelo ensino médio. Uma advertência de Venturi a respeito das novidades no perfil da escolarização da população talvez explique o porquê dos apoiadores no ensino médio serem em número elevado: com a expansão do ensino, o nível médio tem se estendido para os de baixa renda, justificando a força do partido no estrato educacional intermediário simultânea ao crescimento entre os de menor rendimento familiar ${ }^{29}$.

Ao traduzir algumas porcentagens em números absolutos, Ventu[29] "O processo relativamente acen-
tuado de escolarização da população ao longo da última década e meia, com aumento considerável do acesso aos ensinos médio (governo FHC) e superior (governo Lula), fazem do grau de escolaridade um indicador ruim para a observação do fenômeno aqui em foco". Venturi. "PT 30 anos: crescimento e mudanças na preferência partidária", op. cit., p. 204.

[30] Idem ibidem, p. 211.

[31] Gustavo Venturi, Idem ibidem, p. 207.

[32] Samuels, "Sources of mass...", op. cit., p. 312. ri torna patente o tamanho da transição pela qual passa o PT.Em 1997, o partido tinha cerca de 3,1 milhões de simpatizantes de baixíssima renda e 5,5 milhões de alta renda. Já em 2006, os de baixíssima renda pularam para 17,6 milhões e os de alta renda haviam diminuído para 3,3 milhões ${ }^{30}$. Venturi evidencia, igualmente, a perda do partido nas regiões mais ricas, enquanto preservava a conquista nas mais pobres. No Sudeste, a preferência pelo PT cai de $26 \%$ para $19 \%$ depois de 2005 , enquanto no Nordeste ela se mantém, oscilando dentro da margem de erro, de $32 \%$ para $30 \%$. "Ao se recuperarem da crise, um ano depois, o desbalanço na distribuição dos petistas reapareceria, só que agora com o SE abaixo de sua proporção no eleitorado (apenas 37\%) e o NE acima (34\%)"31, diz Venturi. Vale lembrar que o Sudeste contém cerca de $44 \%$ do eleitorado brasileiro, enquanto o Nordeste tem em torno de $28 \%$. A queda da participação de São Paulo no conjunto dos que gostavam do PT, de mais de $50 \%$ para apenas $20 \%$ entre 1989 e 2007 , conforme indica Samuels ${ }^{32}$, vai em rumo semelhante. 
Se olharmos para a composição da bancada federal do PT eleita em 2006 fica claro que, embora ela continue a ser majoritariamente composta de parlamentares eleitos no Sul e no Sudeste, corroborando a percepção de Hunter e Power, a proporção de parlamentares dos Estados mais ricos é menor do que em 2002. Pela primeira vez em sua história, o partido perde assentos na Câmara dos Deputados no Sul, no Sudeste e no Centro-oeste, crescendo apenas no Nordeste e mantendo o número de cadeiras provindas do Norte (Tabela 5) ${ }^{33}$. Quando cotejada com a votação de Lula, que no primeiro turno de 2006 foi derrotado no Sul e no Sudeste, ganhando no Norte e no Nordeste, o partido diferencia-se porainda eleger a maioria dos seus representantes nas regiões mais ricas. No entanto, a participação relativa destas apresenta uma redução, passando o Sul/Sudeste de 62\% para 53\%, enquanto a do Nordeste/ Norte sobe de $30 \%$ para $40 \%$.

Lula obteve rapidamente uma torrente de votos de baixíssima renda, a qual compensou o abandono da classe média, resultando em um desempenho até um pouco superior no primeiro turno de 2006 (48,6\% dos votos válidos) em relação ao de 2002 (46,6\% dos votos válidos). Já o PT sofreu uma subtração, para a Câmara dos Deputados, de 18,3\% dos votos válidos em 2002 para 14,9\% em 200634 .Ou seja, enquanto a candidatura de Lula à reeleição, dotada da enorme visibilidade que dá o exercício da presidência, avançou para o interior, para os pequenos municípios e para os eleitores mais pobres produzindo "a virada a favor de Lula de uma eleição a outra nos estados que registram menores índices de IDH" 35 -, o PT se ressentia das perdas ocasionadas pelo afastamento da classe média nos Estados mais ricos, compensando-as apenas parcialmente com uma penetração moderada nas regiões mais pobres. Lula aumentou em cerca de $50 \%$ a quantidade de votos que recebera, por exemplo, em Pernambuco, enquanto o PT experimentava um acréscimo em torno de apenas 10\% na votação para a Câmara dos Deputados naquele estado ${ }^{36}$. Não obstante, os melhores números do PT para os governos estaduais deram-se no Nordeste e no Norte, com vitórias em disputas importantes, como as da Bahia e do Pará, sem equivalentes nas áreas de maior desenvolvimento.

Consideradas as eleições municipais de 2008 , verifica-se que se os estados do Sul/Sudeste ainda respondem pela maioria dos municípios administrados pelo PT (53\%), essa proporção vem caindo: era de $70 \%$ em 2000 , enquanto a do Nordeste/Norte subiu de $21 \%$ para $33 \%$ entre 2000 e 2008 . O aumento de cidades governadas em apenas quatro estados do Nordeste e do Norte entre 2004 e $2008-$ Bahia (de 21 para 67), Piauí (de 7 para 18), Pará (de 18 para 27) e Sergipe (de 4 para 8 ) - constituiu quase metade das novas prefeituras conquistadas pelo PT na última eleição municipal.
[33] Agradeço a Brandon Van Dyck, doutorando da Universidade Harvard, haver-me chamado a atenção para os dados referentes à Câmara dos Deputados.

[34] Ver 〈www.tse.gov.br〉, acessado em $5 / 7 / 2010$.

[35] Hunter e Power, op. cit. p. 335 . 
TABELA 5

Número de cadeiras do PT na Câmara dos Deputados por região do país, 1982-2006

\begin{tabular}{|c|c|c|c|c|c|c|c|}
\hline \multirow{2}{*}{$\begin{array}{l}\text { Região do } \\
\text { País }\end{array}$} & \multicolumn{7}{|c|}{ Ano } \\
\hline & 1982 & 1986 & 1990 & 1994 & 1998 & 2002 & 2006 \\
\hline Sul & - & 2 & 8 & 12 & 13 & 19 & 14 \\
\hline Sudeste & 8 & 14 & 19 & 24 & 26 & 37 & 30 \\
\hline Nordeste & - & - & 2 & 7 & 9 & 17 & 23 \\
\hline Norte & - & - & 4 & 2 & 5 & 10 & 10 \\
\hline Centro-Oeste & - & - & 2 & 4 & 5 & 8 & 6 \\
\hline
\end{tabular}

Fontes: 1982-2002, J. Nicolau, Dados eleitorais do Brasil (1982-1996), via V. A. de Angelo e M. A. Villa (orgs.), op. cit., p. 118. 2006, TSE, via 〈www.tse.gov.br〉, acessado em 05/7/2010.

Uma análise do desempenho por grau de urbanização também revela modificações no que era predominante até 2000 , quando o PT era o "partido das capitais". Naquele ano, o partido elegeu prefeitos nos centros ricos, com vitórias expressivas no Sudeste e no Sul, vencendo em São Paulo e Porto Alegre. Já em 2008, o PMDB iguala o PT em número de capitais governadas, sendo que as do PT se concentram nas regiões menos desenvolvidas (Nordeste/Norte).A sua força parece deslocar-se para o que Reis, seguindo Bolívar Lamounier, chamou de "metrópoles periféricas" 37.

Nas capitais das zonas desenvolvidas, onde há um importante eleitorado de classe média, o partido foi empurrado para a extrema periferia e até mesmo para fora dos limites municipais, obtendo expressiva votação nos populosos municípios das respectivas regiões metropolitanas, mas perdendo nas cidades principais ${ }^{3}$. Em São Paulo, por exemplo, segundo Fernando Limongi e Lara Mesquita, o PT perde votos dos eleitores com maior escolarização para o PSDB, "enquanto acentua-se a penetração do partido entre as camadas menos educadas", situação que parece se estabelecer com clareza já em 2004 e ficar mais aguda em 200839.

Há uma nítida percepção do sentido da transformação do PT na afirmação do então presidente do partido, Ricardo Berzoini, em março de 2008: "Hoje o PT tem uma força no Nordeste que há quinze anos nem sonhava ter. Em regiões onde o impacto das políticas do governo foi menor, muitas vezes o questionamento ético supera a força das realizações. Depende muito da região e do estrato social" ${ }^{\circ}$. Não por acaso, o próprio Berzoini foi sucedido em 2010, na presidência partidária, por um político do Nordeste (José Eduardo Dutra), região que pela primeira vez designa o principal dirigente do partido. 
Em resumo, os indicadores empíricos corroboram a avaliação de que, entre 2002 e 2006, o partido perdeu parcialmente o apoio da classe média, dos eleitores de alta escolaridade, no Sul/Sudeste e nas capitais centrais que o caracterizava desde a fundação. Por outro lado, ampliou em escala significativa o suporte entre os eleitores de baixa renda, de baixa escolaridade, no Nordeste e no Norte do país, e no entorno das metrópoles ${ }^{41}$.

O realinhamento ocorrido com o PT vai na mesma direção que o lulismo: afluxo de um público pobre e perda de apoio na classe média. Na sua versão atual, a composição do grupo de apoiadores do partido ficou parecida com a da sociedade. Segundo a amostra usada pelo Datafolha em março de 2010,52\% dos eleitores do Brasil, e 47\% dos simpatizantes do PT, estavam na faixa de até dois salários mínimos de renda familiar mensal; $33 \%$ dos eleitores, e $38 \%$ dos apoiadores do PT, na faixa de dois a cinco salário mínimos; 5 e $8 \%$, respectivamente, na camada de cinco a dez salários mínimos; e 4\%, para ambos, na faixa superior a dez salários mínimos. Pode-se dizer que, depois de 2006, o partido ficou muito mais próximo do Brasil do que era até meados dos anos de 1990, mostrando que estava certa a intuição de Juarez Guimarães ao escrever que "o PT tornou-se nos últimos anos mais nacional, mais brasileiro, mais sertão, mais samba, mais negro, mais nordestino e mais amazônico, mais agrário"42. O PT tem hoje cerca de dez vezes mais simpatizantes que vivem no piso da pirâmide econômica brasileira do que entre os que estão no topo, diferença que não existia em meados da década de 1990 .É por ter entrado no coração do subproletariado que o PT adquiriu a feição de "partido dos pobres", lugar vago na política brasileira desde 1989 , quando o PMDB perdeu essa condição.

\section{DO ESPÍRITO dO SION AO ESPÍRITO DE PORTO ALEGRE}

O realinhamento descrito não teria como deixar de ter impacto no espírito do PT, como teria no de qualquer partido. Esse realinhamento incidiu de maneira especial, no entanto, pois, embora nascido (com êxito) para representar camadas subalternas da sociedade, o PT foi, durante vinte anos, o recipiente de uma série de movimentos de classe média - se aceitarmos o paradoxo de que, no Brasil, o proletariado é de classe média, pela simples razão de que sob ele existe uma vasta parcela da população que está aquém da possibilidade de participação na luta de classes, o subproletariado43. A passagem de partido de classe média para partido dos pobres implicou um choque, cujos ecos seguem presentes.

Vindo à luz em um ambiente extensamente influenciado por uma espécie de "revolução democrática" que sacudiu o Brasil nos anos de
[41] É possível que isso explique o fato de, no Encontro Nacional de 2006 , Rachel Meneguello e Oswaldo E. do Amaral terem encontrado um aumento de delegados de menor renda. Ver Meneguello e Amaral. "Ainda uma novidade: uma revisão das transformações do Partido dos Trabalhadores no Brasil". Occasional Paper Number BSP-02-08, Brazilian Studies Programme, Oxford, 2008. Os autores anotam uma queda no número de delegados aos encontros do partido com renda superior a vinte salários mínimos, de $28 \%$ em 1997 para $13,4 \%$ em 2006 , enquanto o número de delegados com renda de cinco a dez salários mínimos foi $19 \%$ para $33 \%$ no mesmo período (Tabela 5).

[42] Guimarães, op.cit., pp. 52-3.

[43] O conceito de subproletariado remete à formulação original de Singer, Paul. Dominação e desigualdade. Rio de Janeiro: Paz e Terra, 1981, p. 22. 
[44] Oliveira, op. cit., p. 20.

[45] Diretório Nacional do PT. Resoluções de Encontros e Congressos. São Paulo: Fundação Perseu Abramo, 1998, p. 48.

[46] Candido, Antonio. Vários escritos. São Paulo/Rio de Janeiro: Duas Cidades/Ouro sobre Azul, 2004, p. 196.

[47] Panebianco, Angelo. Modelos de partido. São Paulo: Martins Fontes, 2005, p.XVII.

[48] Schwarz, Roberto. "Cultura e política, 1964-1969”. In: O pai de família e outros estudos. Rio de Janeiro: Paz e Terra, 1978.

[49] Weffort, Francisco. O populismo na política brasileira. Rio de Janeiro: Paz e Terra, 1978, p. 159.
1980, o PT foi embalado pela aspiração, que se desenvolveu sob a ditadura militar, de que a volta ao Estado de direito ofereceria ao país a oportunidade de um "reinício". Como se fosse possível recomeçar de um novo marco zero - a proclamação de uma verdadeira República -, o PT nasce sob o signo de uma "nova sociabilidade" 44 , simultaneamente democrática e socialista.A proposta de fundação, aprovada em um Congresso dos Metalúrgicos, em janeiro de 1979, falava em criar um partido "sem patrões", que não fosse "eleitoreiro" e que organizasse e mobilizasse "os trabalhadores na luta por suas reivindicações e pela construção de uma sociedade justa, sem explorados e exploradores" 45 .

O caráter radical do partido, que fazia desse traço elemento distintivo em uma cultura política tingida pela ambiguidade e pela conciliação desde o alto, tinha o sentido de negar as limitações dos períodos anteriores. Desconfio que tal radicalismo esteja vinculado a uma tradição que Antonio Candido afirmou ser "essencialmente um fenômeno ligado às classe médias" 46 . Em todo caso, minha hipótese é de que não é possível entender o efeito do realinhamento de 2002-2006 sem levar em conta a origem radical do PT. Conforme afirmou Angelo Panebianco, "poucos aspectos da fisionomia atual e das tensões que se desenvolvem diante dos nossos olhos em tantas organizações parecem compreensíveis se não se retroceder à sua fase constitutiva" 47 .

O golpe de 1964 abriu uma fase de radicalização na história brasileira. Na área cultural, em particular, como mostra Roberto Schwarz $4^{8}$, a derrubada do governo João Goulart ensejou um inesperado crescimento da esquerda, o qual durou pelo menos até a edição do AI-5, em dezembro de 1968. Entre as teses em voga na época estava a de que, na República de 1946, uma tentativa de aliança entre o povo e a burguesia nacional teria predominado às expensas da nitidez de um projeto de classe. A concepção etapista, defendida pelo PCB, teria resultado em prejuízo das classes dominadas, que ficaram desorganizadas para fazer frente à ofensiva militar que, em 31 de março de 1964, jogou por terra os projetos de emancipação acalentados à sombra do populismo.

Nas palavras do cientista político Francisco Weffort, que defendeu tese de doutorado na USP sobre o período populista em 1968,

[...] na adesão das massas ao populismo tende necessariamente a obscurecer-se a divisão real da sociedade em classes com interesses sociais conflitivos e a estabelecer-se a ideia do povo [ou da Nação] entendido como uma comunidade de interesses solidários 49 .

Acrítica ao populismo e ao "partidão" (como era conhecido o PCB) que passou a predominar na intelectualidade de esquerda foi levada aos foros de fundação do PT, quando a abertura trouxe de volta algo da efervescência reprimida em 1964 e 1968. 
A radicalização atingiu também o meio católico, o qual, influenciado pela Teologia da Libertação, desenvolveu, nos interstícios da repressão, uma extensa rede de organismos populares, as Comunidades Eclesiais de Base (CEBs). Iniciada a transição para a democracia, as CEBs, imbuídas de uma perspectiva transformadora, tiveram papel destacado na conformação do PT. Deve-se ao catolicismo boa parte do sentimento radical que caracterizou o espírito que, não por acaso, estamos aqui chamando "do Sion".

Os sindicatos de trabalhadores que cresceram nos recessos da ditadura, representando em parte uma camada operária recente, advinda do "milagre" econômico, propunham igualmente uma ruptura com o velho sindicalismo do período populista. Com o vigor típico dos gestos inaugurais, pregavam a liberdade sindical e a revogação da legislação que, segundo se dizia, inspirada no fascismo italiano, atrelava o movimento sindical ao Estado.

Deu-se, então, um caso raro de associação de pensamento radical com amplas camadas de trabalhadores, como havia ocorrido na Europa um século antes $5^{\circ}$. A singularidade foi notada por Perry Anderson, para quem o PT foi o único partido de trabalhadores de grande proporção criado no planeta depois da Segunda Guerra Mundial51.

$\mathrm{Na}$ atmosfera otimista da redemocratização, sobretudo a partir dos acontecimentos que eclodiram entre 1978 e 1980 no ABC, o PT despertou a atenção do mundo. Afinal, quando em outras partes do planeta a reação neoliberal desmontava o que fora construído no pós-guerra, no Brasil greves de massa pareciam civilizar as "formas bárbaras de exploração capitalista" 52 . O PT soube cultivar o terreno aberto pelos avanços conquistados pela classe trabalhadora no período. Da cultura participativa ao caráter progressista da Constituição de 1988, cumpriu o papel histórico desempenhado pelos partidos operários na Europa, a saber, o de generalizar "dimensões fundamentais da igualdade" 53 .

O discurso voltado "à organização de classe num sentido estrito" 54 obteve êxito entre os trabalhadores industriais, entre as categorias em expansão do setor de serviços, como bancários e professores, e junto aos funcionários públicos. A militância entusiasmada e a autenticidade das propostas fizeram do PT um partido aberto à participação. Fraco do ponto de vista eleitoral, embora em crescimento permanente, o PT ganhava robustez por ser a representação de forças vivas das classes subalternas, enquanto estas tiveram vigor para avançar.

Valendo-se dessas forças, o partido se propôs a combater, mesmo que isolado, os vícios e os arcaísmos do patrimonialismo nacional. Recusou-se a votar em Tancredo Neves em 1985, arcando com o ônus de fragmentar a frente antiditatorial; decidiu não assinar a Constituição de 1988, apesar de seus aspectos altamente progressistas, em
[50] Embora Antonio Candido (op. cit.) advirta para não se misturar pensamento revolucionário e radical, não posso aqui elaborar a necessária distinção, a ser feita em outra oportunidade.

[51] Perry Anderson (2007). "Jottings on the conjuncture". New Left Review, $\mathrm{n}^{\circ} 48,2007$, pp. 5-37, p. 23. Conviria, também, comparar a trajetória do PT com a do PSOE espanhol, "refundado" em 1976, um pouco antes de o partido brasileiro ter sido criado. Ver Camiller, Patrick. "Espanha: sobrevivência do socialismo". In: Anderson, P.e Camiller, P. (orgs.).Um mapa da esquerda na Europa ocidental. Rio de Janeiro: Contraponto, 1996. Camiller mostra que o programa espanhol falava em "partido de classe com caráter de massas, marxista e democrático", rejeitava "qualquer caminho de acomodação ao capitalismo" e visava "a assunção do poder econômico e político, e a socialização dos meios de produção, distribuição e troca pela classe trabalhadora" (p.116).

[52] Luxemburgo, Rosa. "Greves de massa, partido e sindicatos". In: Loureiro, I. Rosa Luxemburgo, textos escolhidos. São Paulo: Expressão Popular, 2009, p. 65.

[53] Souza,Jessé.A construção social da sub-cidadania. Belo Horizonte/Rio de Janeiro, UFMG/Iuperj, 2006, p. 166.

[54] Oliveira. Collor, a falsificação da ira. São Paulo: Imago, 1992, p. 24. 
[55] Diretório Nacional do PT, op. cit., p. 517 . nome de um projeto ainda mais avançado; e por fim recusou o apoio do PMDB no segundo turno de 1989, o qual poderia ter significado a vitória de Lula. Mas à medida que expressava um impulso social florescente, o radicalismo do PT acabou por influenciar a democracia brasileira, deixando vestígios importantes na Carta constitucional. $O$ reconhecimento de direitos fundamentais para a classe trabalhadora e de institutos de participação direta na Constituição deve-se em boa medida à década das greves (1978-1988). O PT, nos anos de 1980, contribuiu para que o Brasil vivesse uma experiência típica de períodos de descompressão em que, como na Espanha e Portugal, aspirações sociais longamente represadas emergem com potência capaz de deslocar o pêndulo da história.

Com a derrota da Frente Brasil Popular, em 1989, inicia-se, no entanto, uma espécie de "restauração". Os governos seguintes buscaram reformar a Constituição recém-promulgada, retirar os direitos obtidos na década anterior e dar um conteúdo liberal à democracia reconquistada. A recessão, o desemprego e a quebra das cadeias produtivas durante o governo Collor demoliram as bases da "revolução democrática": um segmento da classe trabalhadora virou suco (leia-se, exército industrial de reserva) e os sindicatos tiveram que recuar. Com isso, o número de greves nos anos de 1990 despencou. Apesar do impedimento de Collor em 1992, o avanço neoliberal prosseguiu por meio dos dois governos de Fernando Henrique Cardoso. Vencedor das eleições no primeiro turno em 1994 e 1998, e sustentado por ampla coalizão, FHC realizaria de modo sólido e organizado o programa vitorioso em 1989: ajustar o país ao neoliberalismo, anulando as conquistas do período anterior. Nesse processo, dois pontos devem ser destacados. A derrota da greve dos petroleiros em 1995, que quebrou a espinha do combalido movimento sindical, e as privatizações, que realizaram, em alguma medida, a promessa de desmontar o Estado varguista.

No plano ideológico, a queda do muro de Berlim, ainda que libertadora para a esquerda democrática, somou-se à reação interna, fazendo dos anos de 1990 um momento de avanço dos valores capitalistas. Reconhecendo que o quadro havia se transformado, o Primeiro Congresso do PT, em 1991, elabora uma estratégia que busca ampliar o espaço para a luta institucional, uma vez que o movimento social se retraíra. "O PT situa-se, hoje, num terreno mais vasto e complexo da luta de classes. Questões como a combinação da luta de massas com ação de governo [...] apresentam-se como tarefas imediatas" 55 , afirma o texto aprovado na ocasião.

Mas o problema de fundo não podia ser resolvido por meio de resoluções congressuais. Como enfrentar a maré montante da contra-ofensiva burguesa, quando as condições objetivas eram tão desfavoráveis? As dificuldades práticas da tarefa podem ser capturadas 
na análise de Jorge Almeida das campanhas presidenciais de 1994 e $1998^{56}$. No primeiro caso, diz Almeida: "O enfrentamento da questão do Plano Real foi marcado por uma sucessão de indecisões que acabavam sendo percebidas pela população". No segundo, afirma: transmitia-se "insegurança e incerteza, sobretudo em relação ao programa de FHC".

Privado da força motriz que o energizava nos anos de 1980, o PT procura afiançar-se como sigla institucional, o que implicava buscar as alianças recusadas no período inicial. O interessante é que o caráter crescentemente eleitoral do partido, que aparece em 1998 sob a forma de uma associação com o PDT, o que custou a quase extinção do PT no Rio de Janeiro, não é acompanhado por revisão programática fundamental. O encontro nacional de 1998, por exemplo, propunha a "implementação de um programa radical de reformas" que contribuirá "para a refundação de uma perspectiva socialista no país" 57 .É possível dizer que os anos de 1990 representaram a passagem de um partido de tipo "ideológico", cujo anseio por votos se subordina ao caráter doutrinário da campanha, para um partido, "responsável", que busca maximizar votos, mas não altera o seu programa para isso ${ }^{58}$.

Assim, apesar de fazer concessões eleitorais, o PT continuou a ser uma força polarizadora. As diretrizes aprovadas em dezembro de 2001 afirmavam:

\section{A implementação do nosso programa de governo para o Brasil, de caráter} democrático e popular, representará a ruptura com o atual modelo econômico, fundado na abertura e desregulação radicais da economia nacional e na consequente subordinação de sua dinâmica aos interesses e humores do capital financeiro globalizado [grifo meu].

Nessas circunstâncias, o partido esteve próximo ao Fórum Social Mundial, a principal iniciativa anticapitalista do início do século XXI, não por acaso inaugurado no ano 2000 em Porto Alegre, Rio Grande do Sul, o estado mais importante governado pelo PT. Entre o espírito de Porto Alegres9 e o do Sion havia continuidade: ambos expressavam insatisfação com o mundo organizado e moldado pelo capital.

\section{O ESPÍRITO dO ANHEMBI}

Se existe um momento específico que corresponde à irrupção da segunda alma do PT, talvez seja o da divulgação da "Carta ao Povo Brasileiro", em junho de 2002 . Houve, certamente, uma longa gestação anterior, cujos fios podem ser rastreados no mínimo à derrota de 1989 , mas fogem ao escopo deste artigo. No entanto, a silenciosa criatura só veio à luz quando já estavam dadas as condições para que, surgindo
[56] Ver Almeida, Jorge. Como vota o brasileiro. São Paulo: Casa Amarela, 1996, p. 144; Ibidem. Marketing politico, hegemonia e contra-hegemonia. São Paulo: Fundação Perseu Abramo/ Xamã, 2002, p. 188.

[57] Diretório Nacional do PT, op. cit., p. 675 .

[58] A tipologia aqui utilizada é a de Giovanni Sartori. De acordo com o autor italiano, haveria cinco tipos de partido: “(i) partidos de testemunho, que não estão interessados em maximizar votos;(ii) partidos ideológicos, interessados em votos principalmente pela doutrinação; (iii) partidos responsáveis, que não submetem suas políticas e seus programas à obtenção de mais votos; (iv) partidos sensíveis, para os quais ganhar eleições ou maximizar os votos tem prioridade; $e$, finalmente, (v) partidos puramente demagógicos, irresponsáveis, que são apenas maximizadores de votos". Sartori, Giovanni. Partidos e sistemas partidários. Brasília: Editora da UnB, 1982, p. 357 .

[59] Referência ao título do volume editado por Loureiro, Isabel, Leite, José Corrêa e Cevasco, Maria Elisa (orgs). O espirito de Porto Alegre. São Paulo: Paz e Terra, 2002. 
[6o] "Concepção e diretrizes do programa de Governo do PT para o Brasil, Lula 2002". São Paulo, Diretório Nacional do PT, 2002, p. 15.

[61] Coligação Lula Presidente. "Programa de Governo 2002". Brasília, julho de 2002 , pp. 8 e 17.

[62] Ibidem, pp. 17 e 18.

[63] Ver Singer, André. "Raízes sociais e ideológicas do lulismo". Novos Estudos, n ${ }^{\circ} 85,2009$, pp. 83-102.

[64] Diretório Nacional do PT, Concepção e diretrizes, op. cit., p. 27.

[65] Coligação Lula Presidente, op. cit., p. 18. aparentemente do nada, se fizesse imediatamente dominante dentro do Partido dos Trabalhadores. Não sucedeu o vagaroso confronto que por anos opôs, por exemplo, as alas esquerda e direita da social-democracia alemã, até que, na data fatal de 4 de agosto de 1914, o espírito nacionalista tomou conta da organização fundada sob os auspícios de Marx e Engels, sepultando o radicalismo das origens.

Quando a campanha de Lula decidiu fazer as concessões exigidas pelo capital, cujo pavor de um suposto prejuízo a seus interesses com a previsível vitória da esquerda levava à instabilidade nos mercados financeiros, deu-se o sinal de que o velho radicalismo petista havia sido arquivado. Foi, a princípio, uma decisão de campanha, mas cerca de um mês depois o Diretório Nacional, reunido no centro de convenções do Anhembi, em São Paulo, aprovou as propostas antecipadas pela carta, transformando-as em orientações partidárias.

No programa divulgado no final de julho de 2002 pelos partidos que integravam a Coligação Lula Presidente, há um perceptível câmbio de tom em relação ao capital. Em lugar do confronto com os "humores do capital financeiro globalizado" 60 , que havia sido aprovado em dezembro de 2001, o documento de campanha afirmava que "o Brasil não deve prescindir das empresas, da tecnologia e do capital estrangeiro". Para dar garantias aos empresários, o texto assegura que o futuro governo iria "preservar o superávit primário o quanto for necessário, de maneira a não permitir que ocorra um aumento da dívida interna em relação ao PIB, o que poderia destruir a confiança na capacidade de o governo cumprir os seus compromissos", seguindo pari passu o que havia sido divulgado na Carta ${ }^{6}$. Nessa linha, compromete-se com a "responsabilidade fiscal", com a "estabilidade das contas públicas" e com "sólidos fundamentos macroeconômicos". Por fim, assegura que não vai "romper contratos nem revogar regras estabelecidas". Afinal, "governos, empresários e trabalhadores terão de levar adiante uma grande mobilização nacional" 62 .

Como se vê, a alma do Anhembi, expressa no programa Lula 2002, assume um compromisso com a estabilidade, o qual conforme indicamos, em outro lugar, condiz com o sentimento do subproletariado ${ }^{63}$, que começava a se aproximar do partido, e acalmava a burguesia. Enquanto a alma do Sion, poucos meses antes, insistia na necessidade de "operar uma efetiva ruptura global com o modelo existente" 64 , a do Anhembi toma como suas as "conquistas" do período neoliberal: "a estabilidade e o controle das contas públicas e da inflação são, como sempre foram, aspiração de todos os brasileiros"65.

Por certo tempo considerada uma "tática" para facilitar a transição, o ideário ali exposto compunha, na realidade, um segundo sistema de crenças, que passaria a residir definitivamente dentro do peito partido, lado a lado com o que o havia precedido. O compromisso com a 
"estabilidade monetária e responsabilidade fiscal" volta a comparecer no programa presidencial quatro anos depois e "a preservação da estabilidade econômica" continua como diretriz para o governo Dilma Roussef, oito anos mais tarde ${ }^{66}$. A defesa da ordem viera para ficar.

Mudança análoga ocorre no campo da política de alianças. Enquanto a alma do Sion primava pela ênfase ideológica, não aceitando juntar-se sequer a partidos de centro, a do Anhembi aprovou uma chapa formada por Lula e um empresário filiado ao Partido Liberal (PL), agremiação que levava no próprio nome a adesão ao credo oposto ao do PT. Surgido por ocasião da Constituinte para defender argumentos liberais, o PL foi considerado pertencente ao bloco da direita "com base em seu posicionamento relativo nas votações nominais ocorridas durante a vigência do atual regime constitucional" 67 por cientistas políticos que estudaram o assunto. Embora a justificativa para a aliança com o PL fosse a presença de Alencar, nota-se, lateralmente, que a presença evangélica no PL abria canais com setores populares que sempre haviam sido hostis ao radicalismo petista.

O fato de que o empresário José Alencar tenha mais tarde se revelado um homem notável sob diversos aspectos, além de crítico (muitas vezes à esquerda da alma do Anhembi), da política econômica, em particular dos altos juros, não altera que a escolha do PL como parceiro em 2002 mostrava que a intransigência ideológica tinha sido enviada para as calendas gregas. Sinal dos tempos: diferentemente do que ocorrera em 1998, quando a aliança com um partido de centro-esquerda (PDT) obrigou o Diretório Nacional a intervir na seção carioca do PT, a ligação com a direita em 2002 passou ilesa. É que também a opção por uma aliança com segmentos de direita foi tomada, de início, como recurso tático, em um engano que obscureceu a verdadeira natureza do espírito que viria a ser hegemônico. À medida que o governo Lula expandiu o raio de acordos a outros partidos de direita, como o PTB e o PP, deixou de haver quaisquer restrições aos acordos eleitorais. Na eleição municipal de 2008 , a decisão do Diretório Nacional de coibir alianças com o PSDB foi, na prática, ignorada em Belo Horizonte, sem maiores consequências. Em 2010 , a oposição ao acordo com a seção maranhense do PMDB, dominada pela família Sarney, em nome dos velhos princípios, foi derrotada na direção do partido.

Ao estabelecer pontes com a direita sem levar em consideração as razões ideológicas, a alma do Anhembi demonstrou uma disposição pragmática que estava no extremo oposto do antigo purismo petista. Não era uma flexibilização e sim um verdadeiro mergulho no pragmatismo tradicional brasileiro, cuja recusa fora antes bandeira do partido. Sob a aparência de ajustes voltados para o momento eleitoral de 2002, uma verdadeira revolução estava em vigência, deixando atônita boa parte da esquerda sintonizada com o espírito do Sion. Em dezem-
[66]Para 2006, ver Coligação A Força do Povo. "Lula presidente: programa de governo 2007-2010", p. 6. Para 2010, ver Quarto Congresso do Partido dos Trabalhadores. "Resoluções sobre as diretrizes do programa de governo, 2011-2014", item 19a, em 〈www.pt.org.br〉, acessado em 22/2/2010.

[67] Schmitt, Rogério. Partidos políticos no Brasil (1945-2000). Rio de Janeiro:Jorge Zahar, 200o, p. 84. 
[68]Ver Ribeiro, op. cit., p. 195.

[69] Ibidem, p. 197

[70] Ibidem, p. 194, Tabela 1.

[71] Veiga, op.cit.,p.349.

[72] Samuels. "A evolução do petismo (2002-2008)", op. cit., p.310. bro de 2003 , quando foram expulsos os parlamentares que haviam se rebelado contra as diretrizes "renovadas", a maior parte da esquerda permaneceu no PT. Os rebeldes haviam se oposto, em particular, à proposta de reforma da Previdência Social encaminhada pelo governo Lula ao Congresso Nacional. Ao encampar propostas antes sustentadas pelo PSDB, o projeto atendia a reclamos do capital, que via no excesso de gastos previdenciários ameaças à estabilidade das contas públicas. A decisão de excluir do partido os opositores do projeto reformista evidenciava que o espírito do Anhembi não aceitaria desobediência às diretrizes agora mandantes.

Mais tarde, em 2005, o pragmatismo venceu outra batalha significativa. A crise do chamado "mensalão" reabrira o tema do financiamento partidário e, embora por uma diferença de poucos votos, a proposta de "refundação" do partido, que tinha o propósito de resgatar as tradições perdidas, perdeu o PED daquele ano para a corrente que se opunha a uma volta atrás. Estudos posteriores mostraram que as atividades partidárias já não eram financiadas pela contribuição voluntárias dos militantes, como era da praxe inicial, desde meados dos anos de 1990. "Agrande guinada na estrutura de financiamento do PT ocorre em 1996: de um ano a outro, a participação do fundo partidário no total de receitas petistas passa de 12,3\% para mais de $72 \%$ ", escreve Pedro Floriano Ribeiro ${ }^{68}$. A partir de 2000 , teria aumentado também a contribuição das empresas: "Em termos reais (corrigido pela inflação), as doações de empresas ao DN [diretório nacional] quadruplicaram entre 2000 e 2004 ", chegando a $27 \%$ do total arrecadado, contra apenas $1 \%$ em 1999, segundo o mesmo autor ${ }^{69}$. Em contraste, a participação dos filiados no financiamento do partido, que fora de $30 \% \mathrm{em}$ 1989, caíra para menos de $1 \%$ em $2004^{70}$.

Em meio ao torvelinho das novidades, convém perceber que as pesquisas examinadas na primeira parte deste artigo deixam claro que a alma do Anhembi tem raízes sociais; não é apenas um espírito que flutua. A comparação das pesquisas Eseb 2002 e 2006 levou Luciana Veiga a apontar que "em 2006, o PT, na média, representou um eleitorado mais de centro do que em 2002 "71. Igualmente, levantamentos da Criterium e da Fundação Perseu Abramo indicam que, de 2002 a 2006 , a proporção de eleitores situados à esquerda entre os apoiadores do PT caiu de $50 \%$ para $42 \%$, ao passo que a dos situados à direita subiu de $20 \%$ para 30\%. De acordo com Samuels, que utilizou dados de uma quarta pesquisa (Lapop, 2007), "a ideologia esquerda-direita não prediz mais o petismo"72. Segundo o Instituto Datafolha,em 2010, a proporção de apoiadores do PT situados à esquerda teria se reduzido para $32 \%$, ao passo queà direita ela teria subido para $35 \%$ (Quadro 1).A base do PT, que era predominantemente de esquerda, passou a abrigar um contingente análogo de eleitores situados à direita. 


\begin{tabular}{|c|c|c|c|c|}
\hline 2002 (Criterium, 2 de outubro) & $\begin{array}{c}\text { Esquerda } \\
50 \%\end{array}$ & $\begin{array}{c}\text { Centro } \\
6 \%\end{array}$ & $\begin{array}{c}\text { Direita } \\
20 \%\end{array}$ & $\begin{array}{c}\text { NS/NR } \\
23 \%\end{array}$ \\
\hline 2006 (F. Perseu Abramo, 6 de março) & $42 \%$ & $12 \%$ & $30 \%$ & $16 \%$ \\
\hline 2010 (Datafolha, 10 de maio) & $32 \%$ & $16 \%$ & $35 \%$ & $17 \%$ \\
\hline
\end{tabular}

Obs.: As posições na escala de 1 a 7 foram assim agrupadas: Esquerda $=1$ a 3 ; Centro $=4$; Direita $=5$ a 7 .

Fontes: Criterium e Fundação Perseu Abramo, em 〈www2.fpa.org.br〉, acessado em 18/9/2009. Datafolha via Folha de S. Paulo, 30/5/2010, p. A9.

A principal consequência ideológica da configuração recenteé que as idéias anticapitalistas, que o PT herdara do período pós-64 e carregara até as vésperas da campanha de 2002 , resvalam para um segundo plano, fechando longo ciclo cultural aberto com a derrota do populismo. Embora seja um grave equívoco desconhecer que o governo Lula cumpriu parte do programa histórico do partido ao estimular um mercado interno de massa, é verdade que, desconectados de uma postura anticapitalista, os ganhos materiais conquistados levam água para o moinho de um estilo individualista de ascensão social, embutindo valores de competição e sucesso. O espírito do Anhembi, com sua profunda valorização da ordem, é alimentado e alimenta o PT enquanto "partido dos pobres". O êxito eleitoral lhe augura uma dominação prolongada.

DUAS ALMAS E UMA SÍNTESE. (PROVISÓRIA?)

Aspecto peculiar do atual modo petista de vida é que o espírito do Anhembi,embora dominante, não suprimiu o anterior:eles convivem lado a lado, como se um quisesse desconhecera existência do outro.OPT nunca reviu suas posições históricas. Não houve um Bad Godesberg ${ }^{73}$ para retirar do programa os itens radicais. Não ocorreu a exclusão da famosa cláusula 4, momento em que o Partido Trabalhista britânico, conduzido por Tony Blair, abdicou da socialização dos meios de produção. Ao contrário, o Terceiro Congresso do PT, em 2007, reafirmou que "as riquezas da humanidade são uma criação coletiva, histórica e social" e que "o socialismo que almejamos só existirá com efetiva democracia econômica. Deverá organizar-se, portanto, a partir da propriedade social dos meios de produção"74.

Além de disperso em milhares de militantes formados nos anos anteriores ao espírito do Anhembi, o espírito do Sion está nos cadernos destinados à formação dos ingressantes, editados pela direção partidária em 2009. "O Partido dos Trabalhadores define-se, progra-
[73] No programa de 1959, aprovado pelo SPD alemão na cidade de Bad Godesberg, pela primeira vez o partido deixa de fora qualquer menção a Marx e à idéia de socialização das indústrias de base. Ver a esse respeito, Sassoon, Donaldo. One hundred years of socialism. Nova York: New Press, 1996, p. 251.

[74] Terceiro Congresso Nacional do PT. Resoluções do $3^{\circ}$ Congresso do Partido dos Trabalhadores, 30 de agosto a 2 de setembro de 2007. São Paulo: Fundação Perseu Abramo, 2007, p. 16. 
[75] Secretaria Nacional de Formação Política/Fundação Perseu Abramo. "Caderno de Formação", Módulo 1, São Paulo, 2009, p. 25, em «www. pt.org.br>, acessado em 23/8/2010.

[76] Pietá, Elói (org.). A nova política econômica, a sustentabilidade ambiental. São Paulo: Fundação Perseu Abramo, 2010, p. 8, (grifo meu).

[77] Ibidem (grifo meu). maticamente, como um partido que tem por objetivo acabar com a relação de exploração do homem pelo homem", diz um dos textos destinado aos recém-filiados75. Ao descrever a evolução do partido, alude de modo elegante às eventuais incongruências entre teoria e prática: "O PT é um partido de massas e, como tal, permeável às contradições de nossa sociedade e de nossa época". Porém, reafirma o compromisso absoluto com a superação das "desigualdades sociais".

A velha alma é encontrada, também, nas atividades da Fundação Perseu Abramo (FPA), instituída pelo Diretório Nacional em 1996, com o objetivo de "promover a reflexão política, disseminar os conhecimentos produzidos, formar quadros políticos, preservar a memória do partido e da esquerda brasileira"76. Lá, o pensamento que presidiu a criação do PT segue vivo. Na apresentação da coleção de livros que faz o balanço dos mandatos de Lula, Elói Pietá, vice-presidente da FPA, dá ênfase ao fato de ser "inédito ter no governo toda uma geração de lideranças sindicais e populares de esquerda" 77.

Pietá está certo, pois o ethos de origem encontra-se presente no poder executivo federal, onde militantes do PT se destacam por transformar em políticas públicas o compromisso firmado no Sion. A criação do Ministério do Desenvolvimento Social (MDS), por exemplo, que entre muitas incumbências tem a de administrar a Bolsa Família e o Benefício de Prestação Continuada (BPC), colocou no centro do Estado brasileiro a visão de que é preciso avançar de modo consistente no combate à pobreza. Acima de tudo, somadas aos Territórios da Cidadania, sob coordenação do Ministério do Desenvolvimento Agrário, e aos projetos cooperativos apoiados pela Secretaria de Economia Solidária, as iniciativas do MDS procuram dar um caráter emancipatório ao trabalho de resgate dos excluídos.

Pode-se dizer que, de modo amplo, a presença do PT no governo federal organizou-se ao redor de dar materialidade aos preceitos da Constituição de 1988, não por acaso expressão da "revolução democrática" vivida de 1978 a 1988. Em última análise, o partido tem sido o instrumento de construção do Estado de bem-estar social, com aumento do emprego, transferência de renda para os mais pobres e progresso na construção de sistemas públicos de saúde e de educação.

O sentido de democratização radical, característico das origens, influenciou ainda na realização, durante o governo Lula, de dezenas de Conferências Nacionais, inspiradas nas que originalmente se organizaram no campo da saúde e foram decisivas para a criação do Serviço Único de Saúde (SUS). Nas Conferências, milhares de cidadãos mobilizaram-se em torno dos temas mais diversos - desde o meio ambiente aos direitos dos homossexuais - , dando continuidade ao processo de participação aberto pela "revolução democrática" e do qual o próprio PT foi um dos frutos. 
O resultado é que os dois mandatos de Lula à frente do Executivo formaram a síntese contraditória possível das duas almas que hoje habitam o PT. Foi o fato de ter implementado, simultaneamente, políticas que beneficiam o capital e promovem a inclusão dos mais pobres, com uma melhora relativa na situação dos trabalhadores, que permitiu a convivência dos espíritos do Sion e do Anhembi. A unidade dos contrários está expressa nas diretrizes para o período de 2011 a 2014 , aprovadas em fevereiro de 2010. Delas estão excluídos os itens mais característicos de uma e outra fração. Não há menções ao socialismo, mas também não está posto o compromisso de preservar superávits primários altos. Se a "estabilidade econômica" foi incorporada como um valor, ela figura, lado a lado, com a defesa da distribuição da renda como núcleo do próximo governo.

Em consequência, a proposta de programa aprovada pelo Quarto Congresso pode ser lida como o difícil ponto de equilíbrio entre corações que batem em ritmos desencontrados. Não por acaso, o aspecto nacional - que permite a unidade de diferentes classes - ganha relevo. Enquanto, na compreensão antiga, o PT queria não a "adoção de uma política 'desenvolvimentista' que agrega o 'social' como acessório, mas sim uma verdadeira transformação inspirada nos ideais éticos da radicalização da democracia e do aprofundamento da justiça social"78, a solução unitária destaca que "o Governo Lula criou as condições para um Projeto de Desenvolvimento Nacional Democrático Popular, sustentável e de longo prazo para o país"79. Todavia, em lugar de propor a elaboração de leis "para modernizar a atual Consolidação das Leis do Trabalho" 80 , como chegou a ser incluído no programa de Lula em 2002 , assume um "compromisso com a defesa da jornada de trabalho de 40 horas semanais, sem redução de salários" ${ }^{81}$.

É claro que a luta de classes perdeu o lugar central na cena em que fora colocado pelo espírito do Sion. Ela foi substituída, como se vê, por um projeto nacional-popular, que não é incompatível com os interesses do capital. Segundo o programa aprovado em 2010, o Estado deverá promover o "crescimento da renda dos trabalhadores, não só pelos aumentos salariais, mas por eficientes políticas públicas de educação, saúde, transporte, habitação e saneamento", mas, concomitantemente, aprofundar "as políticas creditícias para o setor produtivo por parte do BNDES" e apoiar a "internacionalização das empresas brasileiras" 82 . Trata-se de um capitalismo com forte presença estatal, de distribuição da renda sem confronto, que lembra o ideário varguista.

Para executar tal programa, as alianças necessárias serão feitas, sem atenção para os aspectos ideológicos. Contudo, se equivoca quem pensa estarmos em face de pura maximização.Aconvivência das duas almas do PT leva a paradoxos. O partido defende, simultaneamente, reformas estruturais profundas e a estabilidade econômica; a
[78] Diretório Nacional do PT. Concepção e diretrizes..., op. cit., p. 27.

[79] Quarto Congresso do Partido dos Trabalhadores, op. cit., item 16, em 〈www.pt.org.br〉, acessado em 22/2/2010.

[8o]Coligação Lula Presidente, op. cit., p.30.

[81] Quarto Congresso do Partido dos Trabalhadores, op. cit., item 19p, em 〈www.pt.org.br〉, acessado em 22/2/2010.

[82] Ibidem, itens 19e, 21a e b. 
[83] Terceiro Congresso Nacional do PT, op. cit., p. 24.

[84] Marcelo Ridenti antecipa algo dessa discussão, remetendo para mudanças que já estariam em curso no PT no fim dos anos de 1990 ("Vinte anos após a queda do muro: a reencarnação do desenvolvimentismo no Brasil". Revista USP, $\mathrm{n}^{\circ} 84,2009-2010, \mathrm{pp} .50-7$.

Recebido para publicação em 13 de setembro de 2010 .

\section{NOVOS ESTUDOS}

CEBRAP

88 , novembro 2010

pp. 89-111 propriedade social dos meios de produção e o respeito aos contratos que garantem os direitos do capital; um postulado genérico anticapitalista e o apoio às grandes empresas capitalista; "a formação de uma cultura socialista de massas" $8_{3} \mathrm{e}$ a aliança com partidos de direita. As diferentes descrições da mudança do PT, que apontam ora no sentido da opção maximizadora, ora da manutenção do sentido ideológico original, perdem de vista que o característico da fase que se abre em 2002 é a coexistência de dois vetores opostos em um mesmo corpo partidário. A síntese disponível é, curiosamente, a retomada de uma trajetória sustentada sobre uma aliança de classe, que parecia revogada das possibilidades históricas pelo golpe de $1964^{84}$. Para quem esteve no Sion, é irônico. Para quem assistiu ao nascimento da segunda alma no Anhembi, avançado. As condições objetivas para a ressurreição de tal projeto deverá ser objeto de um esforço de pesquisa. Mas aí já se trata de outro capítulo.

ANDRÉ SINGERé professor do departamento de Ciência Política da Universidade de São Paulo. 